\title{
PERMEABILITY OF INTERLANGUAGE SYSTEM: A CASE STUDY OF STUDENTS LEARNING ENGLISH AS A FOREIGN LANGUAGE AT SMP MUHAMMADIYAH 5 SURAKARTA
}

\author{
Lestari Kelik M. \\ Private English Teacher \\ E-mail: kelikmaryana21@gmail.com \\ No HP: 08132744052
}

\begin{abstract}
The research deals with permeability of students' interlanguage system that reflects in students' composition of SMP Muhammadiyah 5 Surakarta. The aims of the research are (1) to describe what the types of permeability, (2) to describe the source of the influence in students' IL system, and (3) to describe the influence frequency of students' IL system. The type of this research is qualitative research. The data of this research are erroneous sentences found in the students' compositions. The method of collecting data is elicitation and document analysis. The writer uses descriptive analysis by Celce Marcia and a modified framework of Error Analysis by Shridar a technique for analyzing data. The results indicate that (1) the permeability is found at the level of morphology and syntax, (2) the source of the influence is students' mother tongue (Indonesian) and target language (English), (3) the influence frequency of the mother tongue to students' interlanguage system is $48 \%$ and of the target language to the students' interlanguage system is 52\%. The conclusion is that the learners' interlanguage is open to to influence from the outside and influence from the inside language system. It progressively approaches the target language as a result of learners 'attempt on constructing a new linguistic system
\end{abstract}

Keywords: permeability, IL system, mother tongue, target language

\begin{abstract}
ABSTRAK
Penelitian ini berkenaan dengan permeabilitas sistem bahasa antar pada karangan Bahasa Inggris siswa SMP Muhammadiyah 5 Surakarta. Tujuan dari penelitian ini adalah (1) untuk memaparkan jenis permeabilitas, (2) memaparkan sumber pengaruh pada siswa 'sistem IL, dan (3) untuk menjelaskan pengaruh frekuensi siswa sistem IL. Jenis penelitian ini adalah penelitian kualitatif. Data dari penelitian ini adalah kalimat yang salah ditemukan dalam komposisi siswa. Metode pengumpulan data adalah elisitasi dan analisis dokumen. Penulis menggunakan analisis deskriptif dengan Celce Marcia dan kerangka dimodifikasi analisis kesalahan oleh Shridar teknikuntukmenganalisis data. Hasil penelitian menunjukkan bahwa (1) permeabilitas ditemukan pada tingkat morfologi dan sintaksis, (2) sumber pengaruh adalah bahasa siswa ibu (Indonesia) dan bahasa target (bahasa Inggris), (3) pengaruh frekuensi bahasa ibu untuk siswa sistem antarbahasa adalah 48\% dan dari bahasa target untuk siswa sistem antarbahasa adalah 52\%. Kesimpulannya adalah bahwa antarbahasa pembelajar 'terbuka untuk mempengaruhi dari luar dan pengaruh dari sistem bahasa
\end{abstract}


dalam. Ini semakin mendekati target bahasa sebagai hasil dari upaya peserta didik pada membangun sistem linguistik baru.

Kata kunci: permeabilitas, sistem IL, bahasa ibu, bahasa target

\section{INTRODUCTION}

English becomes a global language that demands foreigners to learn it. In Junior High School, English is introduced as one of subjects of the study. Students learn it as a foreign language. English is not easy to be learnt because it consists of four skills. Those skills are listening, speaking, reading and writing. It is difficult to master them because the learners should take into account three language aspects - structure, pronunciation, and vocabulary. Students are limited by a period of time in learning English and English also enlisted in final examination as a means to graduate. As a result it adds the difficulties to learn English.

There are three previous studies related to this study. The first previous research has been done by Hobson (Rhode University, 1999) entitled "Morphology Development in the Interlanguage of English Student of Xhosa". The purpose of this study is to investigate whether the features of interlanguage identified in other studies appear in the learner language in study. He uses a quasi-longitudinal research design as a tool to trace development in the oral interlanguage of six learners of Xhosa for a period of eight month. He also uses case study approach to method of collecting data and the data analysis is primarily qualitative. The result of this study is that learners use morphology from the beginning of the learning process considering agreement and inflectional morphology play a central role in conveying meaning in Xhosa.

The second study is Caneday's research (University of North Dakota, 2001) entitled Interlanguge Coda Production of Hmong Second Language Students of English. The aim of her study is to define and understand the production of syllable final consonants and clusters by Hmong children (ages 9 and 12) learning English using a constraint-based theory. She uses Optimality Theory as a method for conducting her research. First, she lists the targeted coda consonants and consonant clusters. Next, she explains the tasks that were used for her study. Then, she gives a profile of the subjects chosen for her study. Finally, she gives detail on the transcriptions that were made.The results of this study are that Hmong language and the English constraints interacted in an ordered fashion allowing predictable patterns in production. The final consonants and consonant clusters were often deleted or changed by the intermediate Hmong speakers of English, because they have not completely resolved the conflict of what they now in their native language with what they are learning in the English.

The last research is a research conducted by Sarmedi Agus Siregar (University of North Sumatra, 2004) entitled Analisis Antarbahasa (Interlanguage) Pembelajaran Bahasa Inggris di Politeknik Negeri Medan dan Yanada English Centre Medan, Suatu Studi Kasus. He investigates students' interlanguage system in Medan. The results of this study are (1) both interlingual and intralingual transfer are found in the students' interlanguage system, (2) there are some overgeneralization forms found in students' interlanguage system, including the auxiliary insertion, auxiliary substitution, inappropriate use of verb, and inappropriate use of preposition, (3) there are three stages in the students' interlanguage system, those are presystematic stage, systematic stage, and postsystematic stage, (4) the students' interlanguage system includes deviations, those are ortograph deviation, lexicon deviation, and grammatical deviation, (5) the code-switching and code-mixing is found in the students' interlanguage 
system (Sarmedi, 2004).

The writer uses some related theories in this study. An interlanguage is an emerging linguistic system that has been developed by a learner of a second language (or L2) who has not become fully proficient yet but is approximating the target language: preserving some features of their first language (or L1), or overgeneralizing target language rules in speaking or writing the target language and creating innovations. Yip (1995:12) assumes that interlanguage refers to "the susceptibility of interlanguage to infiltration by first language and target language rules or forms."

Adjemian (1976:301) gives contribution to the concept of interlanguage by adding three features of IL. Those are systematicity, fossilization, and permeability. Permeability is one of the keys in language development that makes learner's knowledge at any stage is not fixed but is open to amendment.

Ellis (2000:33) asserts that learner's grammar is permeable. It means the grammar is open to influence from the inside and outside. It can be inferred that students' IL system is influenced by two items namely first language and target language.

From the explanation above, the writer formulates the problem statements of the study as follows: (1) how does the mother tongue system influence in the students' IL system?, (2) how does the target language system influence in the students' IL system?, (3) to what extend does the students' mother tongue influence the students' IL system?, (4) to what extend does the students' target language influence the students' IL system?, (5) what is the difference degree the influence from both the mother tongue and the target language in students' IL system?, and (6) what is the implication of the research result toward English teaching and learning process?

So, the objectives of the study are (1) to describe how the mother tongue system influences in the students' interlanguage system, (2) to describe how the target language system influences in the students' interlanguage, (3) to describe to what extend the students' mother tongue influence the students' interlanguage system, (4) to describe to what extend the students' target language influences the student interlanguage system, (5) to describe the degree of the influences from both the mother tongue and target language in the students' interlanguage system, and (6) to describe the implication of the research result toward English teaching and learning process.

\section{RESEARCH METHOD}

The type of research that is used by the writer is qualitative research. Qualitative research is a type of research that does not use any calculation or statistic procedure. Larsen, Freeman, and Long (1991: 11) state that prototypical qualitative methodology is an ethnographic study in which researchers do not set out to the hypotheses, but rather to observe what it presents with their focus, and consequently the data, free to vary during the course of the observation. The researcher describes types of error and analyzes them by surface strategy of taxonomy. She describes how is students' interlanguage system can be influenced by students' mother tongue linguistic system and target language linguistic system.

The subject of the study is the eighth grade students of SMP Muhammadiyah 5 Surakarta in 2012 school year. The object of this study is erroneous sentences found in students' composition. The researcher takes 40 students' composition randomly and lists them in the frame of erroneous sentence. Those erroneous sentences listed 108.

This research is a study of learners' interlanguage system. Thus, the source of the data is collected from eight grade students of SMP Muhammadiyah 5 Surakarta. Then, the data of this study is erroneous sentences found in the students' compositions. The researcher takes 40 
compositions randomly from three defferent classes of SMP Muhammadiyah 5 Surakarta as suitable data of the research.

In this research, elicitation and document analysis are used as the method of collecting data. Elicitation technique is a technique to lure students to produce their own composition by giving instruction in producing it. In gathering written materials, the researcher uses documentation technique which involves several steps as follows: (1) The researcher gives instruction to write free English composition; (2) The researcher reads each students' composition objectively and cautiously; (3) The researcher writes all the erroneous sentences found in students' composition; (4) The researcher lists them and makes them as the data of her research.

The writer uses descriptive analysis by Celce Marcia and a modified framework of Error Analysis by Shridar (2009:136). The steps of technique for analyzing the data are as follows: (1) in identifying Error, the researcher makes a list of erroneous sentences that are not proper with English rule found in students' English composition; (2) in classification of Error, the researcher classifies the erroneous sentences found in students' English composition based on linguistic category, strategy taxonomy outside, and based on degree of mother tongue and target language system; (3) in identification of sourses of error, the researcher highlights erroneous sentences, influenced by English and Indonesian system, to analyze the source of error; (4) in describing the degree of Influences, the researcher gives the description of influences degree toward mother tongue system and target language system which is mirrored students' interlanguage system; and (5) in drawing conclusion, the researcher draws conclusion from the research results that got to answer the problem statements in this research as the final step.

\section{RESEARCH FINDING AND DISCUSSION}

This part presents the research finding and the discussion of research finding. It will answer the problem statement of this study.

\section{Research Finding}

The researcher uses the framework of Error Analysis proposed by James, Corder, and Shridar to recognize the errors. Those errors are normal occurence in students' learning a foreign language. They have a unique system which different from both mother tongue and target language. It is called interlanguage system. Then, she uses Dulay, Burt, and Krashen (1982) taxonomy in order to present the classification of error descriptively. There are three sorts of errors based on Dulay, Burt, and Krashen taxonomy found in students' composition. Those are linguistic category, surface strategy taxonomy, and comparative taxonomy.

First, in terms of linguistic strategy terms, there are two language components which are affected by errors which contain permeability case. They are morphological and syntax. In the morphological level, the permeability counts for $26.67 \%$. Besides the syntactic level is count for $73.33 \%$.

Second, in terms surface strategy taxonomy, permeability is found in three types of error forms. Those are omission, addition, and misformation. Omission is as $12 \%$ include four different categories with various percentages. Addition is as $3.3 \%$ include addition of article (2\%) and addition of preposition (1.3\%). Misformation is as $4.67 \%$ include regularization $(0.67 \%)$ and alternating forms $(4 \%)$.

Third, the writer found permeable sentence concerning with comparative taxonomy. Errors types based on comparative taxonomy are errors which classified based on "a comparison between the structure of second language errors and certain other type of construction" (Dulay, Burt, and Krashen, 1982:164). In this case, errors in learners' interlanguge do not result 
from first language influence but rather reflects the learners' gradual discovery of the second language system and the learners' mother tongue system may interference the acquiring of target language or transfer into learners' developing second language system. The stage of learners' developing second language system is a stage where learners create a new language system. The system is called interlanguage system which is permeable toward influence of both mother tongue and the target language.

Next, she uses the interlanguage framework introduced by Selinker, Adjemian, and Corder to identify the influence both of mother tongue and target language to the students' interlanguage system. She analyzes the data accurately then she classifies them based on the types and sources influence in students' interlanguage system. As the result, the writer found two sources of the influence in students' interlanguage system. The first is students' mother tongue (Indonesian) and the second is students' target language (English). Both of them have the same chance to give interferrence towards students' interlanguage system, but the research result tells students' target language (English) is the highest influence of it. The influence frequency of students' mother tongue (Indonesian) is 52\% while the influence frequency of students' target language (English) is $48 \%$.

The analysis shows that the percentage of the influence of the mother tongue to the students' IL system is $48 \%$. The influences of the students' IL system include (1) morphological level and (2) syntactic level. The first is the morphological level (5.93\%) including Indonesian abbreviation as 1.3\%, an Indonesian word as 3.33\%, and the use of Indonesian word with slight modification as $1.3 \%$. The second is the syntactic level (42\%) including a literal translation in the use of Indonesian pattern (6\%) and the use of Indonesian pattern in sentences $(36 \%)$.

In addition, the percentage of the influence of the target language (English) to the students' IL system is as $52 \%$. It is greater than the mother tongue influence toward the students' IL system. The influence of English to students' IL system includes: (1) morphological level and (2) syntactic level. First, the morphological level (20.64\%) includes free morpheme as $18.64 \%$ and bound morpheme as $2 \%$. Free morpheme includes (a) false friend, (b) omission of article, (c) addition of article, and (d) misformation. False friend involves words with the similarity in form as $1.3 \%$ and words with the similarity in meaning as $10 \%$. Omission of article is at $0.67 \%$ and addition of the article is as $2 \%$. Misformation includes regularization as $0.67 \%$ and alternating form as $4 \%$. Bound morpheme shows the percentage as $2 \%$, it comes from omission of $-\mathrm{s}$ in plural form. Second, syntactic level $(31.3 \%)$ includes (a) the use of V1 instead of V2, (b) omission of be as copula, and (c) preposition. The use of V1 instead of V2 is at $14.6 \%$ whereas omission be as copula is as $6 \%$. Preposition show the percentage as $10.63 \%$ coming from omission of preposition as $1.3 \%$, addition of preposition as $3.33 \%$, and misuse of preposition as $6 \%$.

The research result shows that learners' interlanguage progressively approaches target language as a result of learners' attempt on constructing a new linguistic system. The new linguistic system is called interlanguage. This study emphasizes on permeability students' IL system by investigating erroneus sentences having permeablility cases. It might give implication to English teaching learning. The implication is addresed to the teachers and students as the subject of education. The first is for the teachers as an important figure in education. The research result enables the teachers to know their problem that they are facing, so that it could lead the language teacher to create or pick a method which is most suitable to teaching English especially in writing. More writing tasks also should be done in order to improve students' writing ability. In addition, one way is that teachers should give an explanation for a new word in English, and in Indonesian when necessary. Another way is to put the word in a given context when introducing a new word to the students. The second is for the students. The students can 
evaluate their composition and improve their ability in producing composition by mastering their problem. The researcher hopes that her study is meaningful for both the student and the teacher in English teaching learning process.

\section{Discussion}

The researcher finding of the recet research shows the most dominant influence of students' interlanguage system is influenced by target language (Englih). The influence frequency of students' mother tongue (Indonesian) is as 52\% while the influence frequency of students' target language (English) is as 48\%. Mostly the students' interlanguage system is influenced by target language (English) especially in syntactic level $(31.3 \%)$. To make the explanation simpler to be understood, the researcher presents the influence frequency of both mother tongue (Indonesian) and target language (English) in a chart.

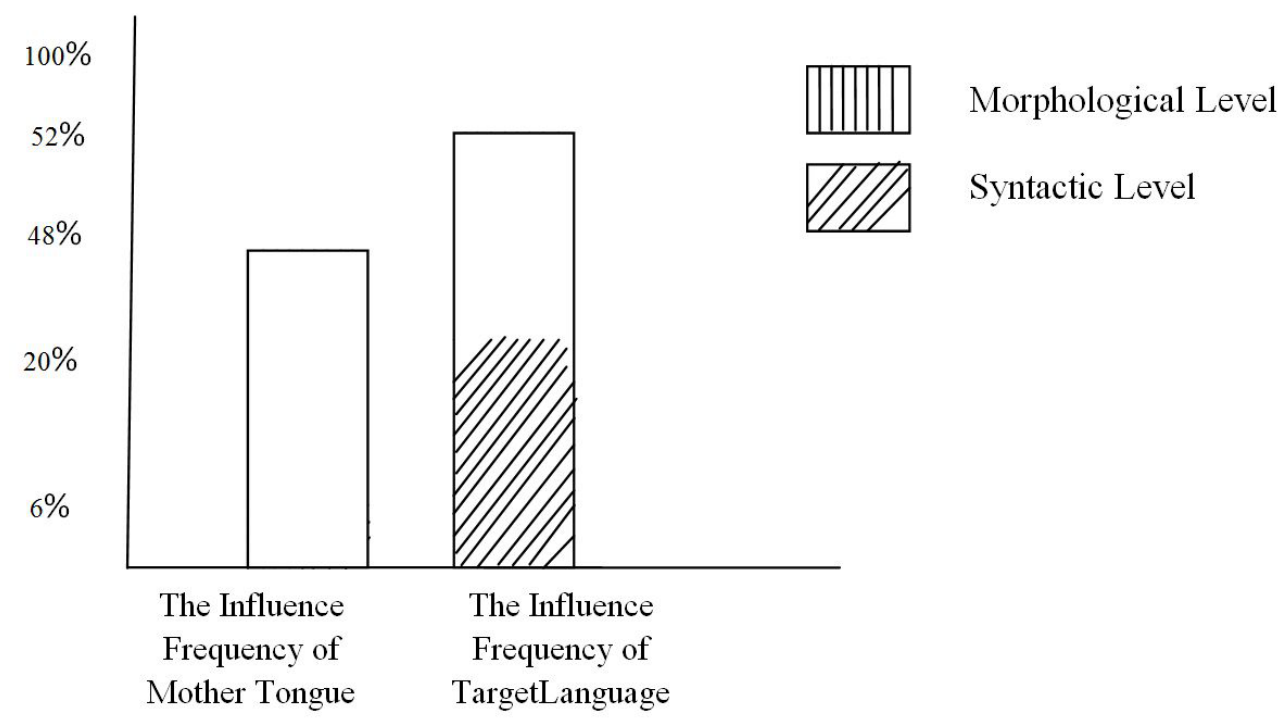

Frequency of both Mother Tongue (Indonesian) and Target Language (English)

Learners' interlanguage system are permeable to infiltration of linguistic elements of the target language. This means the structuere of first language which students' learned second gives chanche to presence of errors. Brown (2000:224) states interlingual transfer is the negative transfer of item within the target language or put another way, the incorrect generalization of rules within the target language. The learners' mother tongue system may interference the acquiring of target language or transfer into learners' developing second language system.

\section{CONCLUSION AND SUGGESTION}

\section{Conclusion}

Based on the previous part, it shows that the theory applied in this research is appropriate. The writer infers that students' interlanguage system is permeable which is open to infiltration of mother tongue (Indonesian) and the target language (English). The influence frequency of students' mother tongue (Indonesian) is $52 \%$ while the influence frequency of students' target language (English) is $48 \%$. Eventually, this study has revealed that the most dominant influence of students' interlanguage system is influenced by target language (English). It also shows that learners' interlanguage progressively approaches target language as a result of learners' attempt on constructing a new linguistic system. 


\section{Limitation and Suggestion}

a. Limitation of the Study and Suggestion

The writer realizes that this paper is far from being perfect. This paper is just limited on permeability as one of interlanguage characteristics in SMP Muhammadiyah 5 Surakarta. What the researcher study is compositions of eight grade students in SMP Muhammadiyah 5 Surakarta. The researcher takes 40 compositions randomly from the subject of this study to study it. There are many weaknesses on this research dealing with the ideas and the theory. Here, the writer hopes that the next researcher will be better and more complete than this research.

For example, the other researcher can conduct a research about systematicity or fossilization of students' interlanguage system in SMP Muhammadiyah 5 Surakarta or even in other schools. The writer hopes that this study will be useful for the other researcher to conduct another study on the same topic but in different perspective or to conduct a further analysis of interlanguage.

\section{b. Limitation of the Findings and Suggestion}

Based on the recent finding, it can be seen that students' interlanguage system influenced by first language (Indonesian) and second language (English). The influence frequency of second language is greater than first language. From those facts, the researcher suggests to the English teacher to improve his ability in using learning strategy. She also want to show that errors still exist in students' written form and errors tell the teacher what needs to be taught. Those errors reflect students' IL system which is permeable. It means that English teacher should give more motivation to the students in order to make the students more productive in producing composition. Giving motivation is not only on writing but also on other English skill—listening, reading, and speaking.

\section{REFERENCES}

Adjemian, C. 1976. "On the Nature of Interlanguage System.” Language Learning. 26: 297320.

Caneday, Renae L. 2001. Interlanguge Coda Production of Hmong Second Language Students of English, University of North Dakota: Masters Thesis.

Corder, S. Pit. 1977. “The Significance of Learners' Errors.” In Jack C. Richards (Ed.) 1997. 19-30

Corder, S. Pit. 1982. Error Analysis and Interlanguage. London: Oxford University Press.

Corder, S. Pit. 1978. "Error Analysis,” in J.P.B. Allen and Pit S. Corder (Eds) 1978:116-155.

Dulay, Heidi; Marina Burt and Stephen Karshen. 1982. Language Two. New York: Oxford University Press.

Ellis, Rod. Second Language Aquisition. 1997. New York: Oxford University Press.

Fauziati, Endang. 1999. Interlanguage Errors in English Found in the Textbooks for Junior High School Studens in Surakarta. Tesis. Jakarta: Program Pasca Sarjana: Universitas Katolik Indonesia Atma Jaya.

Fauziati, Endang. 2008. Reading on Applied Linguistics. Surakarta: Era Pustaka Utama.

Hobson, Carol B. 1999. "Morphological Development in the Interlanguage of English Learners of Xhosa.” Tesis. Afrika Selatan: Linguistik, Rhodes University. 
James, Carl. 1998. Errors in Language Learning and Use: Exploring Error Analysis. London: Longman.

Nemser, William. 1977. “Approximative System of Foreign Language Learners.” In Jack C. Richards (Ed.) 1977: 53-63.

Saville-Troike, Muriel. 2006. Introducing Second Language Acquisition. Cambridge: C.U.P.

Selinker, Larry. 1977.’'Interlanguage.” In Jack C. Richards (Ed.) Error Analysis: Perspectives on Second Language Acquisition. London: Longman.

Selinker, Larry. 1988. Papers in Interlanguage. Occasional Papers No.44, Singapura: SEAMEO Regional Language Center.

Sharwood Smith, Michael. 1994. Second Language Learning: Theoretical Foundation. London: Longman.

Shridar, N.S. 1980. "Contrastive Analysis, Error Analysis, and Interlanguage: Three Phases of One Goal.” In Kenneth Crofth (Ed.) Reading on English as Second Language. 91-119.

Siregar, Sarmedi A. 2004. “Analisis Antar Bahasa (Interlanguage) Pembelajaran Bahasa Inggris di Politeknik Negeri Medan dan Yanada English Center Medan Suatu Studi Kasus.” Tesis. Medan: Program Studi Linguistik, Universitas Sumatera Utara.

Srijono, Djoko. 2001. An Introductory Course of Linguistic. Surakarta: UMS Press.

Tarone, Elaine. 1983. "Some Thoughts of the Nation of Communication Strategy." In Clause French and Gabriele Kasper (Eds.) 1983:61-74

Yip, Virginia.1995. Interlanguage and Learnbility from Chinese to English. Amsterdam: John Nenjamin B.V.

\section{VIRTUAL REFFERENCES}

Hasan, Basturi. 2011. "Interlanguage in Error Analysis Study.” (http://wenku.baidu.com/ view/6aec9c5d804d2b160b4ec0c3.html). Accessed on November 11 $11^{\text {th }}, 2012$.

Rustipa, Katharina. 2011. Contrastive Analysis, Error Analysis, Interlanguage, and Implication to Language Teaching. (http://www.polines.ac.id/ragam/index_files/jurnalragam/ paper_3\%20apr_2011.pdf). Accessed on November $3^{\text {rd }}, 2012$. 